\title{
"OS LIVROS SUJOS BROTAM COMO COGUMELOS": CULTURA IMPRESSA E OBSCENIDADE NO BRASIL (1880-1900)
}

\author{
Érika Cardoso ${ }^{1}$
}

Resumo: Neste artigo propomos uma reflexão sobre a emergência de uma cultura impressa vista como pornográfica no Brasil no decorrer das duas últimas décadas do século XIX. Tanto o termo pornografia quanto o tipo de literatura que ele viria a designar se popularizaram na imprensa e no espaço público brasileiros a partir de 1880, gerando calorosos debates em torno dos malefícios dessas leituras e dos limites do moralmente tolerável no Brasil. Nas páginas seguintes, a ideia é refletir sobre este processo e os discursos que ele ensejou, sobretudo na imprensa da época, baseada nas propostas de autores como Walter Kendrick e Bernard Arcand, para os quais a pornografia deve ser entendida como um reconhecimento social.

Palavras-chave: Pornografia. Moralidades. Literatura.

\section{"DIRTY BOOKS SPROUT LIKE MUSHROOMS": PRINT CULTURE AND OBSCENITY IN BRAZIL (1880-1900)}

\begin{abstract}
In this article we aim to reflect on the emergence of a printed culture considered as pornographic in Brazil during the last two decades of the 19th century. Both the term pornography and the type of literature it would come to designate became popular in the Brazilian press and public space from 1880 onwards, creating heated debates around the harm of these readings and the limits of what was morally tolerable in Brazil. In the following pages, our idea is to reflect about this process and the discourses it engendered. In the following pages, the idea is to reflect on this process and the discourses that it gave rise to, especially in the press of the time, based on the proposals of authors such as Walter Kendrick and Bernard Arcand, for whom pornography should be understood as a social recognition.
\end{abstract}

Keywords: Pornography. Moralities. Literature.

\section{"LOS LIBROS SUCIOS BROTAN COMO SETAS": CULTURA IMPRESA Y OBSCENIDAD EN BRASIL (1880-1900)}

Resumen: En este artículo pretendemos reflexionar sobre el surgimiento de una cultura impresa considerada pornográfica en Brasil durante las dos últimas décadas del siglo XIX. Tanto el término pornografía como el tipo de literatura que llegaría a designar se popularizaron en la prensa y en el espacio público brasileños a partir de 1880, generando acalorados debates alrededor de los perjuicios de estas lecturas y a los límites de lo moralmente tolerable en Brasil. En las siguientes páginas tratamos de reflexionar sobre este proceso y los discursos a los que dio lugar. En las siguientes páginas se pretende reflexionar sobre este proceso y los discursos a los que dio lugar, especialmente en la prensa de la época, a partir de las propuestas de autores como Walter Kendrick y Bernard Arcand, para quienes la pornografía debe entenderse como un reconocimiento social.

Palabras clave: Pornografía. Moralidades. Literatura.

\footnotetext{
1 Doutora em História Social pela Universidade Federal Fluminense (UFF), onde é pesquisadora vinculada ao Núcleo de Estudos Contemporâneos (NEC/UFF).
} 


\section{Introdução}

Em 1883, o responsável pela coluna Livros a Ler da Revista Ilustrada afirmava ter "sobre a mesa um livro cuja torpeza começa logo no título". Escandalizado, ele dizia preferir sequer revelar o nome da obra, "para lhe não fazer o anúncio":

A biblioteca imunda - Leitura para homens - enriquece-se cada dia; os livros sujos brotam como cogumelos.

Certamente deve haver quem os leia: há quem os escreva.

Há gente para tudo nesse mundo. Um porco, que escreveu uma imoralidade, achará sempre outro mais porco que a leia e admire. (Revista Ilustrada, 20/10/1883, p. 3)

Assim como o termo pornografia, pelo qual também eram designadas, as publicações obscenas passaram a ser mais amplamente anunciadas nos jornais brasileiros a partir de 1880. De acordo com Alessandra El Far (2004, p. 79), a maior visibilidade de títulos interpretados como pornográficos nesse momento é um fenômeno indissociável da popularização da cultura impressa de uma maneira geral, processo que se desenvolveu no contexto das transformações de ordem social, cultural e política que caracterizaram as últimas décadas do século XIX. ${ }^{2}$ Nesse período houve uma expansão do mercado editorial brasileiro e, assim como ocorreu em outras partes do mundo, essa expansão incluía o gênero de segunda prateleira ou, como ficaram conhecidas entre os brasileiros, as leituras para homens.

Ao longo das páginas seguintes, minha proposta é investigar como prosperaram, no Brasil, as publicações percebidas como pornográficas e a partir de quais processos elas começaram a "brotar como cogumelos". É importante lembrar, contudo, o que ressalta Alessandra El Far sobre a palavra pornografia na virada para o século XX:

Em nosso mercado editorial, de modo específico, ela foi emprestada às histórias que davam vez às sequências intermináveis de fornicações e cópulas, como também a todo e qualquer enredo que apresentasse em seu texto descrições corporais pouco sutis, namoros proibidos, menções de relações adúlteras ou prazeres que deveriam, em nome dos bons costumes, ter sido reprimidos ou mesmo interrompidos (EL FAR, 2004, p. 194).

\footnotetext{
${ }^{2} \mathrm{O}$ processo se inscreve em um contexto mais amplo. De acordo com Roger Chartier, no século XIX houve uma "revolução industrial da imprensa". Concorreram para o fenômeno o aprimoramento das técnicas de impressão e dos meios de distribuição, aliado a transformações sociais experimentadas de formas e em intensidades diferentes por sociedades distintas, tais como o aumento nos índices de alfabetização e o crescimento urbano, por exemplo (CHARTIER, 1998, p. 16-17).
} 
Trata-se de uma questão importante, uma vez que sinaliza a abrangência de usos e sentidos do termo pornografia nesse período e, consequentemente, a dificuldade em defini-lo. Diante disso, impõem-se o desafio de analisar a pornografia, se ela pode ser qualquer coisa. Eliane Robert Moraes e Sandra Maria Lapeiz (1984), em livro pioneiro sobre o tema no Brasil, reagem à pergunta "o que é pornografia" respondendo o que ela não é. Dada a fluidez da categoria, as autoras optam por concentrar-se onde ela não está, concluindo assim que o mais próximo que se pode chegar de uma definição é compreendendo a pornografia como um ponto de vista.

Proposta semelhante é feita pelo antropólogo Bernard Arcand (1993), para quem a pornografia deve ser investigada como um fenômeno social: "é pornográfico o que a sociedade declara como tal” (1993, p. 28). Já Walter Kendrick (1995) nos convida a pensar a pornografia não como uma "coisa", mas como um "argumento", uma “estrutura de pensamento", sugerindo que prestemos menos atenção nas coisas em si, e mais no que se pensou, sentiu e disse sobre elas: "quais ameaças comunicaram, quais vítimas cobraram, quais redentores douraram e usualmente impuseram a si mesmos uma tarefa redentora" (KENDRICK, 1995, p. 16).

Sendo assim, o caráter pornográfico dos materiais, discursos e comportamentos analisados nesse trabalho é entendido como um reconhecimento social, uma etiqueta, uma percepção, que entre os séculos XIX e XX - e não apenas nesse período frequentemente gerou dissenso entre os interlocutores. Certos livros, entendidos como imorais e obscenos para um leitor, podem não ter escandalizado tanto assim a um outro, e não é meu objetivo determinar qual dos dois estava correto. Não tenho a pretensão de definir a pornografia, mas de refletir sobre sua percepção na sociedade brasileira de fin de siècle, a partir do debate que se deu na imprensa da época. De maneira semelhante, é importante ressaltar que, no Brasil do final do século XIX, alguns livros e estampas, alegadamente capazes de despertar a lascívia, já eram, eventualmente, classificados como pornográficos, mas, também, como Livros e Leituras para Homens ou para Velhos, Livros Picantes, Obscenos, Imorais, Sujos e Gênero Porco. Por essa razão, ao analisar a literatura percebida como pornográfica no período, considero, também, tais sinônimos, amplamente difundidos na época em que circulavam. 


\section{A influência nos trópicos}

Graças ao preciosismo da contabilidade de indivíduos como certo Frei Eugênio ${ }^{3}$, que anotava suas conquistas missionárias ao fim de cada mês, é possível intuir que a obscenidade impressa já circulava, proficuamente, no Brasil desde meados do século XIX, pelo menos ${ }^{4}$. Em 31 de maio de 1871, o frei verificou em seu diário que até aquele momento constavam entre seus feitos missionários a distribuição de terços, comunhões, libertações de escravos e, também, a "apreensão de 685 livros obscenos" e "22 estampas idem”, resultado parcial de sua missão no Rio de Janeiro (Revista do Arquivo Público Mineiro, 1898, p. 710).

Embora não tenhamos a lista dos títulos confiscados por Frei Eugênio, é provável que a maioria consistisse em importações. De acordo com Alessandra El Far (2004, p. 192), até que prosperasse um mercado editorial brasileiro, os leitores eram abastecidos com títulos lusos ou traduções portuguesas de clássicos ingleses, alemães, italianos e, sobretudo, franceses. Ao refletir sobre a circulação transatlântica de impressos no século XIX, Márcia Abreu e Jean-Yves Mollier (2018, p. 10) chamam a atenção para o dinamismo deste fluxo, favorecido pelas transformações técnicas que caracterizam o período de expansão industrial incorporadas por editores, livreiros e empresários teatrais.

Os autores destacam, também, o quanto as noções de centro e periferia podem ser questionáveis no mercado livreiro dos oitocentos, enfatizando a ideia de circulação em detrimento de outra, tradicional, que aponta a França como um polo fixo de irradiação cultural nesse período. Sobre o Brasil, por exemplo, os autores destacam a velocidade com que os romances europeus eram traduzidos em folhetins e a quantidade de leitores.

O mesmo se pode dizer da pornografia, em específico. A influência da França no desenvolvimento de discursos pornográficos em outras sociedades ocidentais é um ponto pacífico entre os estudiosos do tema (HUNT, 1999; GOULEMOT, 2000; KENDRICK, 1995). Ocorre, no entanto, que os estudos mais amplamente divulgados tendem a privilegiar, de maneira quase exclusiva, a experiência francesa, o que resulta

\footnotetext{
${ }^{3}$ Não constam maiores informações sobre a identidade de Frei Eugênio.

4 Não apenas impressas. De acordo com Mello Barreto Filho e Hermeto Lima, o chamado "gênero alegre", nome pelo qual também ficariam conhecidas as diversões mais ou menos obscenas, foi inaugurado no Rio de Janeiro com a inauguração do Alcazar Lyrique, em 1859. Era uma casa de espetáculos onde trabalhavam companhias francesas e, para estes autores, ela teria mudado os hábitos dos cariocas e instituído a vida noturna na cidade. (Apud. MEDEIROS, 1992, p. 21).
} 
em certo silenciamento em relação ao que foi produzido e difundido a partir de outros lugares. Este é o caso de Portugal, por exemplo, cuja literatura obscena, embora tenha sido fortemente inspirada pela França, encerra peculiaridades que influenciaram, em muitos aspectos, o que viria a ser produzido no Brasil.

Um dos títulos mais mencionados pelos jornais brasileiros do século XIX até as primeiras décadas do XX, que nos permite ilustrar a boa recepção da pornografia lusa no Brasil, é, sem dúvida, o Martinhada - poema épico-obsceno (Fig. 1), escrito por Caetano José da Silva Souto-Maior (1694 - 1739), também conhecido como o Camões do Rocio. O conjunto de poemas teria sido uma homenagem ao Frei Martinho de Barros que, reza a lenda, foi um devasso inveterado que fez fama devido às proporções descomunais de seu pênis. Em uma edição de 1849, lemos na "Advertência Preliminar" que seria até redundante pretender demonstrar o sucesso da obra, que em nada deixaria a desejar ao "que possuem os franceses e italianos, tão abundantes, como se sabe, nesta espécie de composição" (SOUTO-MAIOR, 1849, p. 3).

Uma das menções ao Martinhada no Brasil remonta ao ano de 1798 e consta nos autos da Inconfidência Baiana. De acordo com o testemunho do boticário Manuel Joaquim da Silva, este só havia entrado na residência do investigado Luís Pires, vizinha ao seu estabelecimento, uma única vez e, ainda assim, rapidamente, já que o dono não se encontrava presente. Dizia Silva que, em outra ocasião, como queria pegar emprestado um livro, "aliás um poema intitulado Martinhada", esperou por Luís Pires na botica, "lhe pediu o dito papel, que ele emprestou" (Anais da Biblioteca Nacional, p. 152). 
Figura 1: Martinhada - capa da edição de 1849

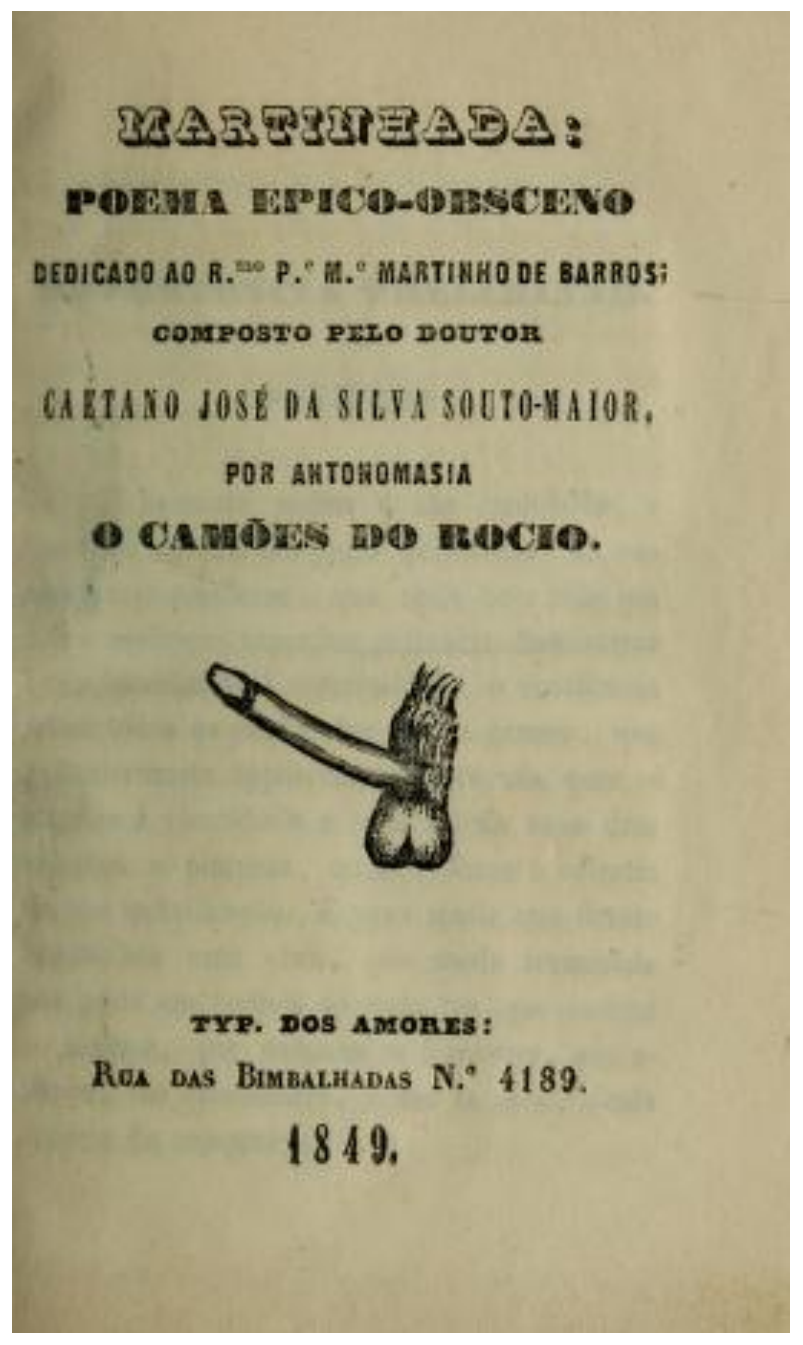

Fonte: Biblioteca Nacional.

Trata-se de um registro muito interessante, pois nos permite pensar nos meios de apropriação desse tipo de leitura no Brasil de fins do século XVIII. Roger Chartier, ao analisar os leitores comumente designados "populares” da Europa renascentista, chama atenção para algumas questões que podem iluminar o debate. Ao refletir sobre os meios de circulação dos livros, o autor nos convida a considerar que "os artifícios de que lançam mão os leitores para obter livros proibidos, ler nas entrelinhas e subverter as lições impostas são infinitos" (CHARTIER, 1998, p. 7).

O Martinhada é importante não apenas pela longevidade de sua circulação no Brasil, mas, também, pela sua incorporação ao imaginário e vocabulário nacionais. Em 1847, por exemplo, um jornal cearense criticava o apelo de certo José Lourenço, que havia sido sentenciado às galés perpétuas, dizendo a respeito da vida do condenado que se "bem espremida nos tipos, poderia pôr em dúvida se seria algum Gil-Braz, Faublas 
ou a Martinhada" ( $O$ Cearense, 07/06/1847, p. 3), fazendo menção a outros clássicos amplamente percebidos como pornográficos nos oitocentos ${ }^{5}$.

Além disso, o título do poema é, frequentemente, empregado como sinônimo de pornografia, de todas as formas de pornografia, algumas das quais pode parecer bastante insuspeitas atualmente. Em 1879, por exemplo, a Revista Ilustrada recorreu à obra portuguesa para manifestar sua indignação com a transcrição feita pelo Jornal do Comércio do "desfaçado bestialógico da câmara municipal, regulando a conduta das casas de tolerância, suas visitas e seu modo de vida, uma perfeita Martinhada" (Revista Ilustrada, 11/10/1870, p. 7). Escandalizava o redator que constassem em páginas dos jornais, de folhas que tinham franca circulação em casas de família, a transcrição integral de assuntos tão escandalosos.

Cabe ressaltar ainda que, a despeito do marco da pornografia moderna ter sido um conjunto de sonetos, o gênero não foi exatamente próspero no ramo da poesia nas experiências francesa e inglesa. Dominique Maingueneau (2008, p. 15), por exemplo, observou que "por natureza, a poesia põe em primeiro plano a materialidade do significante verbal, ali onde a escrita pornográfica privilegia a transitividade da linguagem, que deve se apagar diante dos espetáculos que ela dá a ver"6. De acordo com essa perspectiva, portanto, a poesia não seria "uma forma de escrita bem adaptada ao dispositivo pornográfico", que só funcionaria plenamente na prosa ${ }^{7}$.

Maingueneau, contudo, é um dos autores que se dedica, de maneira exclusiva, aos discursos pornográficos produzidos na França, entre os séculos XVI ao XVIII, onde as principais obras eram relatos em prosa, frequentemente em forma de diálogo. $\mathrm{Na}$ contramão dessa tendência que podemos observar na experiência francesa, no Brasil a obscenidade em versos teve muita popularidade, o que pode ser atribuído ao sucesso de obras como Martinhada e à influência da produção portuguesa.

\footnotetext{
${ }^{5}$ Além da obra do Camões do Rocio, a notícia mencionava a História de Gil Braz de Santilhana e a Vida $e$ Aventuras do Cavaleiro de Faublas, ambos romances franceses libertinos do século XVIII que ganharam traduções portuguesas. Embora Faublas esteja um pouco mais próximo daquilo que hoje entendemos como pornografia se comparado ao Gil Braz, não chegava aos extremos das descrições explícitas contidas no Martinhada. Mesmo assim, permaneceu tanto quanto o poema português no imaginário popular brasileiro, como referência às aventuras burlescas e sensuais. O Cavaleiro de Faublas e o Martinhada compuseram as listas de livros para homens no Brasil até as primeiras décadas do século $\mathrm{XX}$.

${ }^{6}$ No original: «Pour nature, la poésie met en effet au premier plan la matérialité du signifiant verbal, là où l'écriture pornographique la transitivité du langage, censé s'effacer devant les spectacles qu'il donne à voir ». Todas as traduções são minhas.

${ }^{7}$ No original: «La poésie n'est pas une forme d'écriture bien adaptée au dispositif pornographique ».
} 
El Far (2004) chamou a atenção para o "circuito" livreiro que ligava Paris, Lisboa e Rio de Janeiro desde as últimas décadas do século XIX e a partir do qual originais, traduções e adaptações circulavam de maneira bastante ativa. Um belo exemplo dessa dinâmica é a primeira tradução, em língua portuguesa, de um dos maiores clássicos franceses do século XVIII, a Histoire de Dom B... portier des Chartreux. ${ }^{8}$ De acordo Márcia Abreu e Charlotte Gaves (2007, p. 109-125), é possível que essa versão, publicada em 1842, tenha sido obra de um brasileiro.

Traduzido como Saturnino, porteiro dos frades bentos, a capa traz a informação de que foi composta "na impressão do anônimo brasileiro" (Fig. 2). Além disso, os cenários e personagens, originalmente franceses, foram substituídos, no enredo, por congêneres brasileiros. Desse modo, a cidade do Rio de Janeiro e suas redondezas são referidas no início e no desfecho da história, do mesmo modo que os frades Cartuxos são substituídos pelos Bentos que, ao contrário dos outros, eram atuantes no Brasil (ABREU; GAVES, 2007, p. 7).

Figura 2: Saturnino, Porteiro dos Padres Bentos

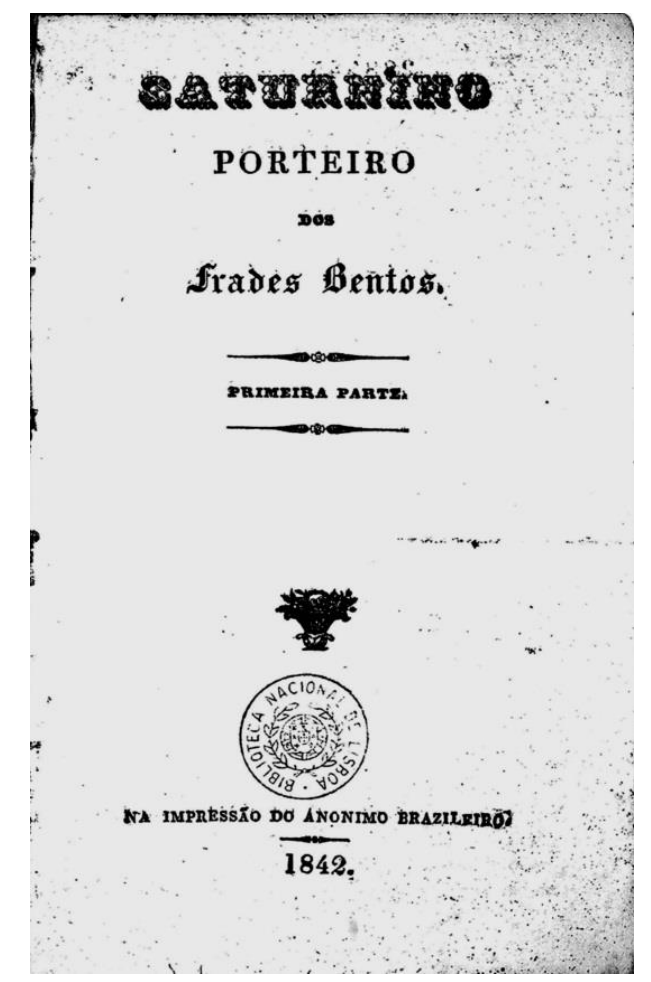

Fonte: Edição de 1842 - Biblioteca Nacional de Lisboa.

\footnotetext{
${ }^{8}$ A obra é atribuída a Jean-Charles Gervaise de Latouche e foi publicada na França entre 1740 e 1741 . O enredo é muito emblemático da literatura pornográfica francesa pré-revolucionária, caracterizada por um forte anticlericalismo que se manifestava tanto na crítica retórica aos dogmas religiosos quanto na narrativa que frequentemente envolvia membros do clero em verdadeiras orgias. (DARNTON, 1997, p. $88)$.
} 
Abreu e Gaves ainda salientam que estas especificidades não são garantia de que a tradução tenha sido elaborada no Brasil. Uma característica muito comum dos clássicos pornográficos do século XVI até meados do XX é a autoria anônima e a indicação de falsas origens e tipografias. Na França, por exemplo, os livros eram submetidos a uma censura prévia e, portanto, traziam no frontispício a autorização real. A literatura obscena, por sua vez, sequer era submetida a esse tipo de crivo e costumava trazer falsas indicações de origem e autoria, de modo a proteger os responsáveis (DARNTON, 1997, p. 21). Essa tática foi muito adotada por pornógrafos de outros países, como o Brasil, onde não havia censura prévia às publicações durante o período analisado.

As autoras, no entanto, recorrem à linguística histórica para demonstrar ser provável que, no caso das peripécias de Saturnino, tais indicações sejam verídicas, ainda que a escassez de fontes comparativas dificulte um veredito conclusivo:

Assim, mesmo tendo feito todo o esforço para manter-se oculto e não revelar sua identidade, o tradutor - ou, eventualmente, o tradutor e o tipógrafo - deixou marcas, onde menos esperava: na forma como empregava pronomes $\mathrm{e}$ interpretava desinências e terminações. A marca do Brasil não se restringe, como se vê, às referências geográficas precisas que, no final do texto, situam a trama no Rio de Janeiro. Vários elementos linguísticos do texto concorrem a confirmar que a referência à cidade não é apenas uma maneira de ambientar as peripécias de Saturnino em um lugar exótico e longínquo, mas o cenário natural para a adaptação do texto francês ao português no e do Brasil. (ABREU; GALVES, 2007, p. 14).

Mas há, também, indícios de obscenidades mais longínquas. Nos Anais da Biblioteca Nacional, por exemplo, está registrada a doação de três obras japonesas, feita por Carlos Von Koseritz à instituição, em 1883. Em carta, de 27 de julho daquele ano, endereçada a Capistrano de Abreu que, na ocasião, era bibliotecário na instituição, o doador esclareceu que entre elas havia "um romance japonês, com texto escrito e ilustração" no qual "há um pedaço cortado, porque era uma pornografia indecente, que por isso cortei” (Anais da Biblioteca Nacional, p. 490). Trata-se de um registro interessante, pois confessa a censura infringida de forma tão radical ao livro, evidenciando os sentimentos conflitantes que podiam gerar nos leitores tais narrativas 9 .

Como jornalista, professor, tradutor e folclorista, o alemão radicado em Porto Alegre Carlos Von Koseritz foi uma figura importante no circuito literário brasileiro dos

\footnotetext{
${ }^{9}$ El Far (2004, p. 259) chama a atenção, nesse mesmo sentido, para a edição de 1893 do romance $O$ Aborto, que compõe o acervo da Fundação Biblioteca Nacional, do qual foram arrancadas justamente as páginas menos ortodoxas da história.
} 
oitocentos, traduzindo e importando livros estrangeiros. Tratava-se, portanto, de um mediador da circulação dessa literatura no país. Além disso, boticários, jornalistas e freis certamente não compõem uma mostra muito variada, que nos permita apontar em suas leituras de alcova um hábito já tipicamente brasileiro nos séculos XVII e XVIII, mas podem sugerir que ao menos entre os homens profissionais e letrados o acesso aos livros pornográficos não era exatamente uma dificuldade. Pouco a pouco as traduções foram sendo abrasileiradas, os cenários passaram a ser as ruas e mosteiros do Rio de Janeiro e as personagens foram substituídas por tipos nacionais (EL FAR, 2004, p. 16).

\section{Pornografia à brasileira}

A despeito dos antecedentes que atestam a popularidade de uma cultura impressa obscena no Brasil desde o período colonial, foi a partir de 1880 que as obras havidas como pornográficas passaram a ter uma maior visibilidade na imprensa e, pelo que dão a entender as notas e reclames, também nas estantes das livrarias. O Rio de Janeiro, especialmente, viveu nesse momento um forte aumento populacional, fomentado em parte pelo contingente de estrangeiros que aqui desembarcavam vindos da Europa, muitos dos quais dispostos a investir no comércio varejista (EL FAR, 2004, p. 29-30). Nesse movimento, alguns editores se preocuparam em angariar segmentos da sociedade que até então encontravam-se excluídos do universo leitor, em razão do alto custo dos livros, criando assim todo um mercado voltado para o "povo" (EL FAR, 2004, p. 11).

Surgiam então os "livros baratíssimos"10, geralmente impressos em papel de baixa qualidade, em formato $1 / 4$ de ofício, encadernados em brochuras, sem o requinte das capas duras destinadas às classes abastadas (EL FAR, 2004, p. 82). Disso resultou que não apenas um número maior, mas também mais variado de pessoas, pôde se entreter com narrativas das mais diversas, entre quais, as que se destacavam pelo teor sexual. Desse modo, a difusão de leituras havidas como pornográficas deu-se no bojo de um lento processo de popularização das práticas letradas, de uma maneira geral.

Na imagem, a seguir, vemos um dos anúncios da Livraria do Povo na Gazeta de Notícias, publicado em 1882 (Fig. 3).

\footnotetext{
${ }^{10}$ A expressão foi amplamente utilizada nos anúncios de jornal. El Far (2004, p. 85) demonstra que, de fato, eram baratíssimos. Nos anos 1880 era possível adquirir brochuras por valores entre 100 e 1 ou 2 mil réis, e no início do século XX, mesmo com a alta da inflação, os preços variavam entre 3 e 4 mil réis.
} 
Figura 3: Anúncio de 1882 da Livraria do Povo

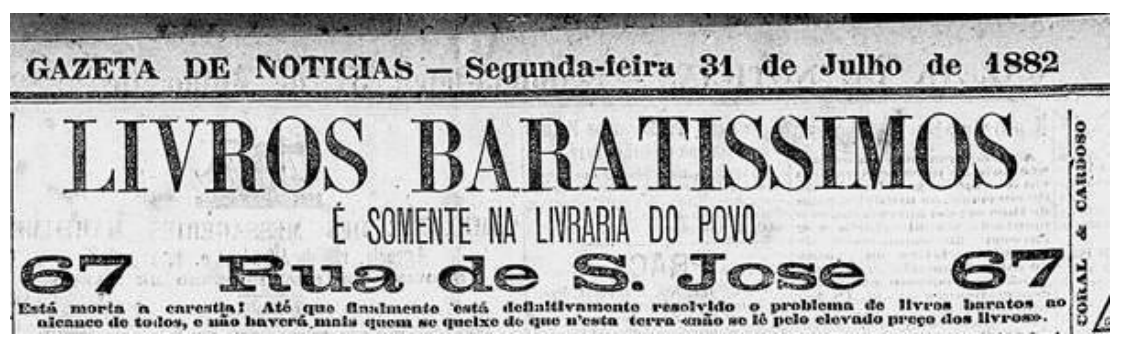

Fonte: Gazeta de Notícias - Fundação Biblioteca Nacional.

Nesses anúncios era possível encontrar títulos que podemos supor senão totalmente brasileiros, pelo menos traduções bastante abrasileiradas. Entre eles estavam, por exemplo, Gravetos realistas, cenas e orgias das cortesãs do Rio de Janeiro nas sociedades carnavalescas, Uma Orgia no Catete ${ }^{11}$ ou Os Amores da Brasileira, O monge de Glinda ou o frade criminoso protegido pela polícia no crime de rapto perpetrado no Recife; Um matuto do Pernambuco que abriu sete botões numa noite; Romance de uma freira por uma carioca; A virgem de Itamaracá, ou a donzela perdida debaixo da mangueira. Há, inclusive, enredos que se pretendem resgates históricos de façanhas sexuais empreendidas pelos brasileiros do passado, como A legendária Gabriela, que tantas proezas fez quando a companhia de Jesus aportou às plagas de Santa Cruz.

Mas a profusão de livros havidos como pornográficos e ameaça que ela comunicava também foi frequentemente alardeada por aqueles que pretendiam combatê-la. Em 1896, por exemplo, foi publicado em $O$ Apóstolo um artigo no qual diversos termos e máximas cientificistas foram invocados, sem que se abandonassem totalmente as ideias de "valores" e "tradição", para sustentar o argumento de que a pornografia já havia superado as raias do intolerável no Brasil.

Sob o título A grande epidemia, o autor iniciava com a reflexão de que "a onda pornográfica" seguia "inundando o campo social com suas fétidas imundices". Isso daria a dupla sensação, segundo ele, de que "a moral e a religião" estivessem carentes de "garantias" ou que "o governo e a polícia, desmoralizados por sua fraqueza e tolerância, não dessem sinal de vida". O autor prosseguia, expressando que "os excessos que se ostentam e traficam de todas as formas e em todos os lugares" marchavam intensamente, "dominando e sufocando os bons costumes".

\footnotetext{
${ }^{11}$ Gazeta de Notícias, 04/10/1883, p.4.
} 
Em seguida ele hierarquizava as pornografias que, tão poderosamente, ameaçavam a paz social:

Não falamos só desta nojenta e real, que nua infecciona as ruas mais frequentadas desta cidade, a qual nem sempre é a mais temível. Pior que ela e mais corruptora e perigosa, é esta que em artigos, anedotas e gravuras destila veneno, incutindo na inteligência e coração da mocidade corrosivos princípios. (O Apóstolo, 24/04/1896, capa).

De acordo com esse ponto de vista, a pornografia impressa seria "pior", "mais corrupta e perigosa" que todas as imoralidades passíveis de serem encontradas na rua, inclusive a prostituição, pois as "as publicações por demais livres, quer em jornais, quer em livros", que "tão francamente" estariam propagando "o obsceno, o impuro, a imoralidade", causariam "mais estragos no corpo social do que as mais agudas enfermidades físicas". A perspectiva seria tão avassaladora que as advertências, sinalizando que tais leituras eram destinadas unicamente aos homens, não eram respeitadas:

Não há dúvida de que esta licença de costumes infecciona tudo em suas águas encharcadas e saturadas de miasmas pútridos bebe com avidez tanto o menino como o velho, tanto a donzela como a mãe de família, levados pela curiosidade ou influência do meio.

$[\ldots]$

Somos contrários, e nem poderíamos deixar de ser, à liberdade que tem a prostituição nesta cidade, cujas ruas são às vezes sentinas; mas terá ela concorrido mais para a corrupção dos costumes, o esquecimento da moral, a destruição da harmonia doméstica, do que a pornografia da imprensa, dos teatros e dos romances?

Não! Esta é mais perigosa e de mais nocivos frutos e de mais desastrados efeitos. (O Apóstolo, 24/04/1896, capa).

Para o jornalista, as provas da calamidade moral em que vivia o Rio de Janeiro estariam "à vista de todos que leem as folhas diárias ou outros jornalecos que se publicam por aí". No seu entendimento, além de potencialmente pornográficos, esses jornais se dignavam a anunciar "com aplausos" o "livro realista" e "imoral" em vias de ser publicado para "provocar, despertar a curiosidade e chamar a atenção de quantos o leem” (O Apóstolo, 24/04/1896, capa).

Seria impossível, dessa forma, manter moralizadas as famílias e fazer imperar o respeito na sociedade, pois todos se achavam "profundamente intoxicados". Seriam incompreensíveis os "pais de família" que levavam as fillhas aos teatros e não afastavam de casa "esses focos de miasmas que lhe levam a imprensa livre, as gravuras indecentes e os romances imorais". Segundo ele, a pornografia era "explorada todas as formas" por 
que constituía "uma indústria" e seria escandalosa a inércia das autoridades diante de sua ostensividade:

Grita-se contra a sujidade das ruas, pede-se os cuidados da Junta de Higiene contra qualquer perigo à saúde pública, exige-se o saneamento para prevenir-se as doenças contagiosas! E o mundo moral se deixa em criminoso abandono, como se não produzisse epidemias que matam o espírito e não poucas vezes os corpos! (O Apóstolo, 24/04/1896, capa).

Embora $O$ Apóstolo fosse especialmente profícuo e eloquente nas denúncias do que seus redatores compreendiam como pornográfico, a opinião de que as leituras imorais constituíam uma ameaça, particularmente alarmante, era partilhada por outros veículos de impressa. Em 1883, um jornalista da Revista Ilustrada dizia que as colunas policiais haviam noticiado a prisão da "preta Joanna" que estaria dizendo obscenidades pela rua. Incomodava-o, profundamente, que houvesse punição para os que proferiam imoralidades, mas não para os que as escreviam: "o livro indecente é ainda mais perigoso do que a preta desbocada; a preta vai-se, o livro fica; as obscenidades de Joanna voam, esquecem-se, as obscenidades do livro ficam escritas" (Revista Ilustrada, 20/10/1883, p. 3).

Em 1899, foi a vez do jornal A Imprensa lançar uma crítica feroz contra Lenita, classificado como "romance pornográfico" e "novela sórdida", cujo autor havia se disfarçado "na covardia de um pseudônimo". Dizia a nota que já chegava "às raias do desaforo o descaramento literário de certos indivíduos" que impingiam ao público "leituras enxertadas das mais desbragadas imoralidades, só compatíveis com a garotagem farroupilha dos prostíbulos" (A Imprensa, 15/05/1899, p. 2). Esse é um dos raros episódios em que o enredo é descrito. De acordo com a crítica, na história eram narradas:

\footnotetext{
Descaradamente as cenas mais indignas, os detalhes mais horrorosos da prostituição, num estilo escancarado e sem recatos, como as imprecações de uma bêbada, num beco depravado, respondendo às vaias insolentes de uma canzoada de vagabundos.

E não fica só nisto o desplante do ousado Rabelais de fancaria, que se propõe a corromper as almas inexperientes com a sua monografia pustulenta, sem dúvida um produto da sua psicologia de devasso, que se aprofundou na crapulagem até perder em absoluto as noções mais elementares da moral. (A Imprensa, $15 / 05 / 1899$, p. 2).
}

A indignação do autor dessa crítica com o conteúdo do livro nos contempla com uma oportunidade preciosa de compreender os motivos pelos quais tais livros eram tão 
intoleráveis para determinados segmentos da sociedade. Ele prossegue, descrevendo o seu conteúdo:

Perfis de mulheres viciosas, de velhos encanecidos na devassidão, de jovens transfigurados pela bestialidade dos instintos confundem-se com nomes de cavalheiros e senhoras conhecidas nas páginas desse livro ignóbil, que parece ditado pelo demônio e escrito por um sátiro, no intuito exclusivo de aniquilar o pudor.

Os vícios mais assombrosos da legendária Sodoma, as cenas mais repelentes da decadência latina são aí doutrinadas metodicamente, aplicadas ao nosso meio, como que para instruir viciosos e fazer prosélitos. (A Imprensa, 15/05/1899, p. 2).

Essa opinião aponta, ao menos, dois aspectos em Lenita que soam imperdoáveis ao jornalista. Um deles diz respeito à difamação. Ao que tudo indica, o romance citava nomes de pessoas conhecidas, ou pelo menos insinuava o envolvimento delas nas aventuras narradas. Essa foi uma estratégia muito utilizada em romances havidos como pornográficos desde a França pré-revolucionária que, além de operar como intriga e chantage, dava à narrativa um estatuto de verdade (DARNTON, 1997, p. 216). Mas o jornalista também condenava a intencionalidade. De acordo com ele, o livro havia sido escrito com o "intuito exclusivo de aniquilar o pudor". Assim, seria impossível perdoar o autor de Lenita por abordar temas tão indesejáveis se não havia nessa empreitada nenhuma crítica, nenhuma observação, nenhuma utilidade além da possibilidade de excitar sexualmente.

A questão da intenção é alvo de bastante polêmica. Por um lado, ela é, constantemente, invocada no debate por aqueles que pretendem desabonar uma narrativa a partir do argumento pornográfico, como é o caso desse jornalista. Isso seria muito comum, por exemplo, no caso dos romances publicados sob a rubrica do naturalismo, cujos autores foram, eventualmente, acusados de camuflar suas verdadeiras intenções pornográficas no escopo dessa escola literária.

Por outro lado, os pesquisadores da pornografia também costumam recorrer à intenção, como Jean-Marie Goulemot (2000, p. 149), por exemplo, para quem a narrativa pornográfica é, necessariamente, elaborada com o objetivo único e exclusivo de excitar sexualmente. Dominique Maingueneau (2008, p. 15) faz um adendo nessa tese, acrescentando que a atitude do leitor, ou seja, a intenção de se excitar, cumpre um papel determinante nesse processo.

Trata-se de uma questão capciosa. É inegável que existem narrativas - e outras expressões artísticas - elaboradas com esse propósito. No entanto, não me parece 
prudente ou eficaz definir a pornografia a partir de um critério tão volátil. A confusão mais recorrente que resulta desse método é que a pornografia seja percebida onde seu autor diz que não há. Mas, por mais inusitado que possa parecer, acontece, também, de alguém declarar que produziu pornografia e ser, energicamente, desmentido ${ }^{12}$. Desse modo, embora existam elementos que transcendam a natureza sexual ou o caráter explícito da representação a partir dos quais se pode presumir que determinadas obras foram intencionalmente concebidas com a intenção de despertar a libido, não é isso que define a pornografia.

Para alguns comentadores brasileiros do período analisado, no entanto, a intenção era não apenas determinante como, facilmente, verificável. A voga das escolas Naturalista e Realista popularizava "temas escabrosos" entre o público leitor e, para muitos, o argumento de esses autores que pretendiam expor as mazelas sociais não eximia alguns deles da pecha pornográfica, enquanto para outros críticos as passagens desagradáveis poderiam ser escusadas se houvesse um propósito edificante. Não era essa a opinião do jornalista de A Imprensa a respeito de Lenita. Por fim, ele repreende o autor pela obra:

Ora, é simplesmente incrível que uma pessoa se ocupe na confecção de um livro de tal ordem, sem outro fim que não o de propagar a crápula e tornar mais conhecidos os antros da devassidão.

Arquitetar com palavras tão vergonhoso libelo contra a moral, importa na prática de um crime hediondo, que ao menos devia encontrar repressão na energia policial. (A Imprensa, 15/05/1899, p. 2).

O Carbonário, jornal que sofria constantemente a acusação de pornográfico por parte de outros veículos da imprensa, era um dos que também se queixavam com frequência da profusão de pornografia na capital. Noticiou, por exemplo, que andavam pelas ruas uns menores:

sobraçando grandes maços de fascículos de uma pornografia desbragada, que os vendedores intitulam P... das famílias. Esses impressos são proibidos, mas não se ocultam [...]. A leitura é de uma linguagem Bocajiana desbragada [...] é uma coisa monstruosa pela imoralidade que encerra, além de que tem pretensões a estereotipar costumes de algumas famílias brasileiras. (Carbonário, 17/11/1886, p. 2).

\footnotetext{
12 Os casos mais exemplares, nesse sentido, talvez sejam o da escritora brasileira Hilda Hilst e do escritor britânico Alan Moore. Hilst publicou nos anos 1990 a sua Trilogia Obscena, composta pelos livros $O$ caderno rosa de Lori Lamby, Contos d'Escárnio - textos grotescos e Cartas de um sedutor, declarando, em diversas ocasiões, que se tratava de pornografia. Embora parte da crítica tenha ficado horrorizada, uma outra parcela concluiu que isso fosse apenas um expediente para vender mais livros. Já Alan Moore publicou em 1991 com sua esposa, a ilustradora Melinda Gebbie, o romance gráfico Lost Girls. Não obstante ambos tenham anunciado a obra como pornográfica, grande parte da crítica diz que não é.
} 
É interessante observar que, não obstante os constantes reclames às autoridades, a legislação imperial não previa, muito claramente, a questão da obscenidade impressa e mesmo a República só viria a regulamentar o tema de forma específica na década de 1920. Era, portanto, amparados por esta intolerância sem respaldo legal que os jornais invocavam as autoridades contra o acreditavam ser uma onda de indecência.

Em outra ocasião, o Carbonário chamou a atenção do chefe de polícia para a publicação de Celsa do Amarante, de autoria de Izidoro de Castro, "esse moço que não faz questão de ligar seu nome a escritos escandalosos" que "caem nas mãos das incautas donzelas, mais para pervertê-las do que para instruí-las" (Carbonário, 23/04/1883, p. 1). Já A menina dos três vinténs, classificou como "imoralíssimo", destinado "a satisfazer a curiosidade pueril dos blasés e das mulheres histéricas, dignos consumidores de quanta patifaria literária produz a mente enferma de meia dúzia de escritores pornográficos que por aí andam" (Carbonário, 24/08/1888, p. 2).

Nesse ponto, é interessante destacar a questão do gosto. Ao criticar Izidoro de Castro, fica evidente que o redator ressalta, sobretudo, sua falta de compostura, sua baixeza em não se incomodar por ser associado a assuntos desse naipe. Vejamos, portanto, que o rótulo pornográfico não macula somente os objetos aos quais é atribuído, mas, também, os indivíduos que os produzem e consomem.

\section{A ameaça dos maus livros}

Nesse sentido, é importante ressaltar que, no final do século XIX - e não apenas nesse período -, as leituras havidas como pornográficas comunicavam um perigo para determinados segmentos da sociedade. Enquanto os textos licenciosos circulavam de forma mais restrita eles não geravam tanto temor, não eram motivo de preocupação e não havia uma legislação dedicada a regulamentá-los, mas quando se tornaram públicos e não apenas um número maior de pessoas, mas, também, uma maior variedade delas teve acesso a esses materiais, eles se tornaram um problema (HUNT, 1999).

Entre os grupos sociais que, historicamente, foram alvo de uma maior vigilância neste sentido, destacam-se as mulheres, os jovens e a classe trabalhadora. No caso das mulheres, durante o período analisado, tanto os padres, arautos da tradição católica, quanto os médicos e juristas, paladinos do cientificismo higienista, concordavam, ainda que com motivações diferentes, que elas possuíam os nervos e as carnes demasiadamente frágeis para que resistissem aos efeitos perniciosos de determinadas leituras (EL FAR, 2004, p. 185; 189). Não por acaso, no Brasil, o conteúdo sexual de 
um livro tornava-o uma leitura para homens: a exclusividade proposta no rótulo não significa que as mulheres não o tenham consumido, naturalmente, mas indicam o público alvo preferencial dessa literatura.

Os perigos atribuídos aos efeitos da leitura pornográfica nas mulheres foram bastante comentados. El Far (2004, p. 199) lista, em seu estudo os efeitos que a medicina previa para as onanistas, em especial: após sofrer de flacidez das carnes às erupções cutâneas, as insistentes poderiam morrer lenta e dolorosamente. Além disso, supunha-se que a pornografia poderia levar as mulheres ao lesbianismo. Uma menção a essa tendência foi feita pelo jurista Francisco José Viveiros de Castro (1934, p. 12), que apontou como uma das consequências possíveis da leitura pornográfica em mulheres o "vício" do lesbianismo.

Em seu livro, dedicado às "aberrações do instinto sexual", são mencionados alguns romances que, segundo ele, tratavam o tema sexual "com certa moderação e reserva", mas são rechaçados outros que, "sob o pretexto de estudarem um caso patológico", apresentariam "o vício em todas as suas particularidades obscenas e cruas", "descrevendo-a como a mais delicada e a mais divina de todas as sensações". Para o autor, tal expediente despertaria nas mulheres "curiosidades terríveis":

Duas amigas se encontram, falam do romance que ambas leram, experimentam ao vivo a sensação que o escritor tão ardentemente descreveu, gostam do ensaio, transmitem adiante a descoberta, iniciam outras no segredo. E Safo assim vai conquistando adeptos, propagandistas de seu culto. (VIVEIROS DE CASTRO, 1934, p. 12).

É importante ressaltar, contudo, que, no século XIX, o receio de mulheres leitoras não se restringia às obras havidas como pornográficas. Martyn Lyons (1999), ao analisar a disseminação das práticas letradas na Europa do século XIX, destaca dois aspectos importantes do processo: a inclusão de mulheres, crianças e operários no universo de leitores e a popularização do romance. Como esse próprio autor salienta, os novos leitores, rapidamente, tornaram-se alvo de preocupação para os setores de elite da sociedade. Seus hábitos e preferências literárias causavam desconfiança e inspiravam certo desprezo.

Em relação às mulheres, especificamente, Lyons salienta uma importante mudança nos seus hábitos de leitura a partir do século XIX. Se até então a imagem mais amplamente difundida de uma mulher letrada a associava às leituras de orientação religiosa, no oitocentos, ela se tornou uma consumidora voraz de livros de culinária, 
revistas e romances baratos (LYONS, 1999, p. 166). O romance, ao mesmo tempo em que era considerado apropriado ao público feminino, por supostamente não exigir grandes esforços intelectuais - coisa que os preconceitos dominantes supunham incompatível com a "condição feminina" -, representavam uma ameaça:

O romance poderia excitar as paixões e exaltar a imaginação feminina. Poderia incentivar expectativas românticas que pareciam pouco razoáveis; poderia sugerir ideias eróticas que a ameaçavam a castidade e a boa ordem. O romance do século XIX era, pois, associado com as (supostas) características femininas de irracionalidade de vulnerabilidade emocional. (LYONS, 1999, p. 169).

Uma resenha publicada na Revista Ilustrada sobre o "romance realista" Lili, de Elysiario da Silva, dizia se tratar de uma história curta, que narrava a trajetória da "infeliz" protagonista, "uma jovem malcriada, que lê maus romances e que se perde em cinco pequenos capítulos". Sobre o aviso de que se tratava de uma "leitura para homens", dizia o redator:

Porque este aviso? O que significa essa reserva? As senhoras não podem lê-lo então? É, pois, um livro imoral, indecente?

E é o próprio autor que o diz, na capa, em grossas letras! [...]

Um livro imoral... que o sexo sedutor e seduzível não pode ler... (Revista Ilustrada, 13/10/1883, p. 5).

A própria heroína, portanto, cuja perdição foi auxiliada pela leitura de maus romances, justificava a necessidade das precauções quanto ao acesso feminino a esse tipo de entretenimento.

A premissa que sustenta os cuidados com esse tipo de literatura e especialmente com que tipo de leitor ela terá - é a de que "o livro obsceno obriga à passagem ao ato" (GOULEMOT, 2000, p. 62). Mais do que os efeitos físicos que a pornografia provoca, ela "engendra maus hábitos" (GOULEMOT, 2000, p. 149). A masturbação é, presumivelmente, o mais imediato deles, mas as narrativas podem, ainda, dar o exemplo, inspirar práticas que não são socialmente admitidas ${ }^{13}$.

Desse modo, mesmo a sexualidade masculina, que não foi - e não é - alvo das mesmas interdições, mereceu atenção. A libertinagem não era, exatamente, incentivada, muito menos a do trabalhador, cuja interdição se baseava na crença de que as classes populares se ordenavam por valores morais frouxos, mas cabe ressaltar que sustentava

\footnotetext{
13 Tal prerrogativa é muito frequentemente evocada pelos enredos pornográficos. A famosíssima heroína que dá nome ao clássico Teresa Filósofa, por exemplo, só consentiu na penetração vaginal por não resistir às leituras da biblioteca secreta de seu amado conde, que incluíam outros clássicos como Portier des chartreux, e L'Académie des dames. (QUIGNARD, 2007, p. 25).
} 
as desconfianças o temor de que os "vícios", provocados pela incontinência sexual, repercutiam em muitos âmbitos da sociedade.

Como aponta Jurandir Freire Costa (1983), o homem incontinente apresentava, primeiramente, o risco do contágio físico. Ele contaminaria suas parceiras, sua esposa e, consequentemente, sua prole, o que não era admissível em uma sociedade tão preocupada com a degenerescência da Nação. Seu comportamento perverso poderia, ainda, induzir esposa e filhas à "prostituição". Mas, além disso, o incontinente - ou libertino, como o chama esse autor -, seria avesso ao trabalho, que era um valor a ser defendido. No imaginário médico da época, portanto, era preciso “drenar" a energia sexual masculina para o lar e para o trabalho (COSTA, 1983, p. 243-245). Nesse sentido, o consumo de leituras aditivas, havidas como pornográfica, poderia desvirtuar esse homem, arruinar sua família e, consequentemente, comprometer o meio social.

Em relação aos jovens, sabemos que a desconfiança era a de que poderiam ser, especialmente, atraídos pela literatura havida como obscena. Paulo Sérgio do Carmo (2011, p. 226), por exemplo, cita a experiência de Pedro Nava com os "livrinhos de putaria" que circulavam pelo Colégio Pedro II, no início do século XX. Dizia ele que eram, facilmente, adquiridos em bancas de jornal e engraxates de toda a cidade e se dividiam em três categorias: álbuns de fotografia, cuja qualidade variava bastante e eram os mais escandalosos; os narrativos e as pequenas histórias de escândalo e crime.

O poeta Luiz Edmundo (2005), comentando certos hábitos de adolescência em um bilhete enviado à João do Rio, recordou as leituras que fazia "à socapa pelos dormitórios e recreios", na época do internato. Entre os autores e obras que cita, e que segundo ele eram "os livros em voga nos colégios urbanos daquela época", estão "Júlio Verne, Hugo, Boisgobey, Eça e Balzac, num caos profundo de onde a literatura picaresca, às vezes, surgia numa brochura de Rabelais ou num opúsculo de versos pornográficos, sempre de autor desconhecido". Como o poeta nasceu em 1878, podemos supor que sua incursão juvenil à literatura tenha ocorrido, mais ou menos, em meados da década de 1890, e sua fala sugere que essa era uma iniciação comum a essa geração:

Isso apenas prova o meu início incolor e apagado como o de quase toda gente, que vem desde o padre que ensina os clássicos e prega moral até o livrinho obsceno de literatura de alcova, que a gente põe nos forros e cavas da manga, na ânsia importante de escondê-los aos bedéis. (EDMUNDO, 2003, p. 99). 
A preocupação com a sexualidade dos jovens também perpassava a ideia de que o desregramento punha o corpo social em risco. Nesse sentido, a masturbação foi combatida com especial afinco, de acordo com Jurandir Freire Costa (1983). A lista de consequências físicas e mentais apresentadas pela medicina da época era tenebrosa. E como o hábito era compreendido como um vício, fazia-se necessário impor medidas profiláticas, como forma de impedir que se alastrasse. Costa (1983) discorre sobre as políticas implementadas em colégios internos que, como todo ambiente repleto de garotos enclausurados, era, então, compreendido como um foco potencial do "vício". As precauções envolviam, segundo esse autor, o cuidado com a disposição e formato das carteiras, estímulo à prática de exercícios físicos, alimentação adequada e, evidentemente, a distância de estimulantes sexuais (COSTA, 1983, p. 188-189).

A sexualidade das mulheres, trabalhadores e jovens, portanto, era uma preocupação de Estado. Em 1903, o Correio da Manhã publicou uma crônica intitulada A nossa desgraça, na qual essa premissa é resumida de forma bastante interessante. Seu autor queixava-se da "avalanche de jornais" repleto de "misérias" que eram publicados diariamente. Embora a leitura desses jornais tenha causado repulsa no cronista, ele supõe que, em outras pessoas, os efeitos seriam diferentes.

No seu prognóstico, graças a esse tipo de entretenimento, "o lavrador deixará de lado a enxada”, “o operário abandonará a sua máquina”, "a mulher irá deliciar-se com a crônica do último escândalo", "a rapariga irá aprender sobre a crônica do dia segredos de prostituição, requintes de pornografia, ali postos, às escancaras". Seu argumento era o de que, para "um público impressionável" como esse, esse tipo de leitura representava "um envenenamento constante". Era necessário, ao contrário, instruí-los de outra forma: "Para o despertar, para o fazer crer no futuro, no trabalho, na honra, era outra coisa a oferecer a este povo" (Correio da Manhã, 15/06/1903, capa).

Arcand (1993), ao refletir sobre a fama corruptora da pornografia, apresenta o seguinte paradoxo: se o gênero exibe de forma tão vulgar e asquerosa a sexualidade, isso deveria gerar repulsa por parte do público, mas, ao contrário, a pornografia representa um perigo que ameaça, sobretudo, a família. E no caso brasileiro, por consequência, a Nação.

Nos discursos em torno da pornografia, empreendidos na imprensa brasileira de fin de siècle, é possível notar, por um lado, a ideia de que a popularidade dos livros - e demais divertimentos - percebidos como pouco castos representava um nível de imoralidade jamais experimentado. Esse era um signo da modernidade, mas, também, 
uma de suas mais graves ameaças. Por outro lado, nota-se, também, a percepção de que o alegado atraso social brasileiro em relação às nações europeias era devido - e perpetuado - pela frouxidão de nossos costumes. Nesse sentido, a pornografia - ilustre representante dessa falha nacional - era, também, entendida como um entrave à própria modernidade.

Portanto, a pornografia - tudo aquilo que se entendeu, sentiu e se disse sobre ela - pode revelar-se uma fonte bastante rica para que possamos compreender melhor nosso passado, não apenas no que diz respeito à sexualidade em si, mas, também, em relação aos anseios, aos receios e às projeções de uma sociedade em transformação.

\section{Referências}

\section{Fontes consultadas}

- A Imprensa (Fundação Biblioteca Nacional - Rio de Janeiro);

- Anais da Biblioteca Nacional (Fundação Biblioteca Nacional - Rio de Janeiro);

- Carbonário (Fundação Biblioteca Nacional - Rio de Janeiro);

- Correio da Manhã (Fundação Biblioteca Nacional - Rio de Janeiro);

- Jornal do Comércio (Fundação Biblioteca Nacional - Rio de Janeiro);

- Revista do Arquivo Público Mineiro (Fundação Biblioteca Nacional - Rio de Janeiro);

- Revista Ilustrada (Fundação Biblioteca Nacional - Rio de Janeiro);

- O Apóstolo (Fundação Biblioteca Nacional - Rio de Janeiro);

- O Cearense (Fundação Biblioteca Nacional - Rio de Janeiro).

\section{Bibliografia}

ABREU, Márcia e MOLLIER, Jean-Ives. Nota introdutória: circulação transatlântica dos impressos - A globalização da cultura no século XIX. In: GRANJA, Lúcia e LUCA, Tânia Regina de (Org.). Suportes e mediadores: a circulação transatlântica dos impressos (1789-1914). Campinas, SP: Editora da Unicamp, 2018.

ABREU, Márcia e GALVES, Charlotte. A circulação clandestina de romances e o mistério do "anônimo brasileiro". In: Remate de Males, n. 21, v.1, 2007, p.109-125.

ARCAND, Bernard. El jaguar y el oso hormiguero: Antropologia de la pornografia. Buenos Aires: Edciones Nueva Visión, 1993.

CARMO, Paulo Sérgio do. Entre a luxúria e o pudor: a história do sexo no Brasil. São Paulo: Octávio, 2011.

CASTRO, Francisco José Viveiros de. Atentados ao Pudor: estudos sobre as aberrações do instinto sexual. Rio de Janeiro: Editora Freitas Cardoso, 1934.

COSTA, Jurandir Freira. Ordem médica e norma familiar. Rio de Janeiro: Graal, 1983. 
CHARTIER, Roger. A aventura do livro: do leitor ao navegador: conversações com Jean Lebrun/ Roger Chartier. São Paulo: Imprensa Oficial do Estado de São Paulo: Editora UNESP, 1998a.

A ordem dos livros: leitores, autores e bibliotecas na Europa entre os séculos XVI e XVIII. Brasília: Editora Universidade de Brasília, 1998b.

DARNTON, Robert. Os best-sellers proibidos da França pré-revolucionária. São Paulo, Companhia das Letras: 1997.

EDMUNDO, Luís. O Rio de Janeiro do meu tempo. Brasília: Edições do Senado Federal, 2003.

EL FAR, Alessandra. Páginas de sensação: literatura popular e pornográfica no Rio de Janeiro (1870 - 1924). São Paulo: Companhia das Letras, 2004.

FOUCAULT, Michel. A História da Sexualidade: I - A Vontade de Saber. $13^{\circ}$ ed. Rio de Janeiro: Graal, 1988.

HUNT, Lynn. A invenção da pornografia: Obscenidade e as Origens da Modernidade. São Paulo: Hedra, 1999.

GOULEMOT, Jean-Marie. Esses livros que se leem com uma mão só: Leitura e leitores pornográficos no século XVIII. São Paulo: Discurso Editorial, 2000.

LAPEIZ, Sandra Maria; MORAES, Eliane Robert. O que é pornografia? São Paulo: Brasiliense, 1984.

LYONS, Martyn. Os novos leitores no século XIX: mulheres, crianças, operários. In: CAVALLO, Guglielmo; CHARTIER, Roger (Org.). História da leitura no mundo ocidental 2. São Paulo: Editora Ática, 1999, p. 165-197.

MENEZES, Lená Medeiros de. Os estrangeiros e o comércio do prazer nas ruas do Rio (1890-1930). Rio de Janeiro: Arquivo Nacional, 1992.

KENDRICK, Walter. El museo secreto: La pornografia em la cultura moderna. Colombia: Tercer Mundo, 1995.

MAINGUENEAU, Dominique. $O$ discurso pornográfico. São Paulo: Parábola Editorial, 2010.

QUIGNARD, Marie-Françoise. Préliminaires. In : L'Enfer de la bibliothèque: Éros au secret. Paros: BnF, 2007, p.25-27.

SOUTO-MAIOR, Caetano José da Silva. Martinhada: poema épico-obsceno. Rua das Bimbalhadas. Tipografia dos Amores, 1849.

Artigo recebido em 28 de maio de 2021. Aceito em 13 de julho de 2021.

Revista Escritas do Tempo - v. 3, n. 8, mai/ago 2021 - p. 51-72 